\title{
The European Brotherhood of Lawyers: The Reinvention of Legal Science in the Making of European Private Law Harm Schepel ${ }^{*}$
}

March 2007

\section{Not Published Version}

\begin{abstract}
Against the historical backdrop of the codification debate in nineteenth century Germany, this article traces the reassertion of 'legal science' as an autonomous source of European legal integration in current legal and political discourse about the harmonization of European private law. The article argues that a grasp of widely shared ideas about the role and function of legal science and legal scientists is vital both towards an understanding of the extraordinary impact of the academic project of a European civil code on legal and political discourse in the Union in particular and towards furthering the theory of legal fields in general.
\end{abstract}

Keywords: $n / a$

*h.j.c.schepel@kent.ac.uk

Brussels School of International Studies

University of Kent at Brussels

Boulevard du Triomphe 109

1160 Brussels

Belgium

Tel. + 3226411729

Fax: +3226411720

Biographical statement:

Drs (Amsterdam), LLM (IISL Oñati), Ph.D.(EUI Florence), Reader in Law at Kent Law School, Co-Director of the Kent Centre for European and Comparative Law, Deputy Director of the Brussels School of International Studies, University of Kent.

Acknowledgements:

Thanks to Jacobien Rutgers, Christian Joerges and three anonymous reviewers for good advice and criticism. The usual disclaimer applies. 


\section{Introduction}

Is legal science a source of European legal integration? The question may seem absurd to the readership of this journal. After all, "there is no Wissenschaft at common law!" (Legrand 1997, 54). And social scientists concerned with the majestic role that law has played in the construction of Europe conceive of legal integration not as an autonomous legal process, but as a function of something else - political interests, social mobility or economic exchange, or some combination of these (Alter 2001, Stone Sweet and Fligstein 2002, Stone Sweet 2004). My claim in this regard is fairly modest: law is more than a mere conveyer belt of 'something else' - the legal field is thicker than that. And the way in which lawyers conceive of themselves and of their profession goes to the heart of the vital question of how the legal field maintains both its autonomy and its authority (Bourdieu 1987, Madsen and Dezalay 2002). There is a long and proud European history of legal scientists elevating themselves to the lofty heights of lawgiving and nation-building - a history that has been repeating itself in the process of European legal integration in general and is doing so with particular clarity in the current debates over the harmonization of European private law. As Jürgen Basedow notes approvingly, "legal scholars transcend the traditional limits of the analysis of legal development and try to shape the future European law themselves." (Basedow 1998, 125) This is not, however, the legal science of building conceptual heavens accessible only to those who drink themselves into forgetfulness of terrestrial human affairs (Cohen 1935). This is a legal science that seeks, through a cluster of intellectual, social and political practices, to bolster its claims of authority by claiming to embody, represent and further some profound historic and 
cultural sense of 'European-ness' that lives on in 'the people.' In European law generally, this claim has long manifested itself in two interrelated but distinguishable strands of dominant legal thought (Schepel 2004a). One is essentially ideological, and defines 'European legal culture' as law-as-science. The idea here is that one of the underlying structural similarities between different societies in the Union is a culture associated with 'the rule of law': the authority of general abstract rules, administered by legal experts under exclusion of laypeople, and the systematization of law by legal science. Abstraction, legalism, and amor intellectualis: these are not mere features of a particular legal system in a particular stage of historical development, they are constitutive of the very identity of Europe (Guterman 1966, Wieacker 1990, Häberle 1994). The second strand is evolutionary and is a variation on basic Weberian themes: as society evolves inevitably to liberal capitalism, law evolves inevitably to law-as-science. Capitalism presupposes rational social action which in turn presupposes a calculable legal system and administration bound to rational rules of law: formal legal rationality replaces substantive legal rationality (Weber 1978). Crafted and administered by a highly specialized legal profession, law detaches itself from its socio-cultural (and national) grounding and becomes amenable to the universally applicable best solution. The European Union and its legal framework here play the role of a rationalizing force, liberating civil society and the market from the shackles of political parochialism and legal nationalism (Schepel and Wesseling 1997, Bach 1999).

These themes are reinforced spectacularly in the intellectual foundations, social construction and political support structure of the project of a European civil code. 
However unlikely it is at this stage that such a code will be enacted anytime soon, the enterprise behind it has been a startling success by almost any other measure. It has involved the rapid establishment and expansion of a whole new field of academic enquiry, a remarkably influential effort at political agenda-setting, and a healthy success rate in attracting public funding. This article seeks to trace the importance of the assertion of 'legal science' in the construction and maintenance of the field of European private law both internally and externally. Though my lack of sympathy for the project should be obvious enough, the purpose here is not to discuss the merits of the idea of a European civil code or indeed of the 'softer' options of private law harmonization now on the table: the aim of this article is simply to provide some insight into the import of the notion of a European brotherhood of lawyers united by a profound common attachment to 'scientific truth' in the framework of a particular legal field.

\section{Legal Science and the German Civil Code}

The logical historical reference point for the field of European private law is the intellectual and political history of the German civil code in the nineteenth century (John 1989, Whitman 1990), not least because it arguably represents the heyday of the political importance of legal scientists (Vogenauer 2005). In truth, the import of this history in current legal thought is usually reduced to one aspect of it, the exchange between two eminent scholars, Thibaut and Savigny, on the desirability of enacting a civil code for the whole of fragmented Germany. Anton Thibaut considered such a possible codification as "the most beautiful gift from heaven" the German people could receive, achieving two things at once in the real world: on 
the one hand, such a code would "create similar customs and habits, and this similarity has always had a magical influence on a people's love for and loyalty to country." On the other, codification was sheer necessity since the German states could only maintain their economic welfare by "lively, inner, and reciprocal" circulation and exchange hampered by legal diversity and Volksegoismus (Thibaut 1814, 32-33). Seemingly of equal importance to him, codification would also do a world of good to legal academia and legal education, encouraging the free movement of professors and legal ideas (Thibaut 1814, 27-29). It was not so much these political and practical considerations or even the aim of national legal unity that Savigny famously objected to; what he found appalling was the suggestion that such a code could be written in a few years by enlightened rational jurists as a testament to Vernunftrecht, the Law of Reason. The law, so he argued, lives and breathes in the spirit of the people, not in reason (Savigny 1814). Against Thibaut's specific project, then, he posited the necessity of historical research into the origins and contents of legal principles; against, presumably, any idea of codification he posited the organic character of the law that can only be stifled by enactments of all-encompassing legislation:"ii indeed, he explicitly substituted an "organically progressive legal science" for Thibaut's legislator (Savigny 1814, 161).

It is the debate on the role of legal science not just in relation to political decisionmaking but also in relation to social life that provides the second historical parallel to current activity. Part of what makes Savigny so elusive for modern sensibilities is his counterintuitive assertion that the German Volksgeist was essentially to be revealed in Roman (and not Germanic) law and hence, inevitably, only accessible to a class of very learned jurists (Gale 1982). But this was to be seen as a natural 
product of societal evolution and the division of labor in society: the law, which had once belonged to the people as a whole, now lived organically in the consciousness of learned lawyers which, however, "represented" in some meaningful way the collective consciousness of the people (Savigny 1814, 12; $1840,45)$. As Mathias Reimann puts it, "the growth of law, the path of the Volksgeist, was the organic development of its intellectual principles" (Reimann $1990,854)$. If Savigny was forced by his "organic" theory to stop just short of calling legal science a "source of law;;"iii his successor in Berlin, Georg Friedrich Puchta, had no such problems. He distinguished two forms of Juristenrecht: on the one hand, legal science is receptive in as much as learned lawyers are the "natural representatives and depositories of national legal consciousness." This kind of Juristenrecht is mere customary law, drawing its authority from external sources. From purely internal sources - rationality, truth, correctness -comes the authority of the other kind of lawyers' law: where learned jurists carry "scientific truths," legal science becomes a productive activity and squarely takes its rightful place next to legislation and customary law as a source of law (Puchta 1854, 42-43; Vogenauer 2005). The law "was no longer a product of history, but a creature of logic." (Reimann 1990, 864) With Puchta, then, starts the Begriffsjurisprudenz (Haferkamp 2004), a conceptual jurisprudence that also gave new impetus to the scientific study of the "pure" Roman law of the "pandects" (Whitman 1990, Wieacker 1996, Stein 1999). This Pandektenwissenschaft, in turn, was to have an enormous influence on the eventual German civil code, the Bürgerliches Gesetzbuch (BGB) of 1900, not least through the efforts of one of its leading figures, Bernhard Windscheid, author of the famous and widely admired Lehrbuch des Pandektenrechts (Windscheid 1870) and a member of the first drafting 
commission. Indeed, the BGB has frequently been called a "Windscheidian pandect treatise in statutory form." (Reimann 1990, 867). This pre-eminence of elitist abstraction did not, of course, go unchallenged: indeed, Julius von Kirchmann famously declared the nation "tired of learned jurists." (Kirchmann 2000, 45; Beseler 1843)

The political implications of the role of legal science in the determination of the law form represent the third important historical parallel with current debates. Begriffsjurisprudenz, again with Reimann, "knew only of contract, tort, and property, but nothing of labor conflict, railroad accidents, and unsanitary living conditions. ${ }^{\text {,iv }}$ (Reimann 1990, 867) The intense political debate over private law was cast in scientific terms as a debate over the true source and character of the law between the 'Romanists' and the 'Germanists.' Even if Germanists could be as fond of conceptual abstraction from terrestrial human affairs as most Romanists were, and even if the political import of the Roman law scholarship of the time is subject to debate (Whitman 1990, Reimann 1991), the general position of Germanists was relatively clear: whereas Roman law was anachronistic, elitist, politically oppressive, inherently individualistic and concerned first and foremost with the protection of private autonomy, Germanic law was much more in tune with the values of current society - the importance of legal protection of the disadvantaged and the emphasis on community and family (John 1985, 347; Gierke 1898). The debate over the issues of social justice of private law was eventually settled by a series of compromises, and most notably by the rather extensive use of separate pieces of 'social' legislation as a quid pro quo for the 
maintenance of the pristine logic and systematic coherence of the BGB itself (John 1989).

\section{The Enterprise of European Private Law}

It would be hard to think of an area of law in the Member States of the European Union today that is more firmly rooted in national cultures and academic traditions and more impenetrable to outsiders for its idiosyncratic conceptual and technical sophistication than private law. And yet, it would be harder still to find an academic legal discipline that is flourishing as much as 'European private law.' (Schmid 1999; Hesselink 2002) Specialized academic journals are thriving, ${ }^{\vee}$ voluminous learned tomes on 'European' tort and contract law have appeared (Von Bar 1998,

2000; Kötz 2000), publishers are producing dedicated series of books, ${ }^{\text {vi }}$ courses and modules are offered throughout the continent, collections of conference papers come out in a steady stream (Hartkamp 1994; Müller-Graff 1999; Van Hoecke and Ost 2000, Grundmann \& Struyck 2002; Vogenauer and Weatherill 2006), chairs and graduate schools are dedicated to the subject, and a variety of lavishly funded transnational research projects is producing libraries full of work (Wurmnest 2003): the lus Commune school is uncovering common principles through a series of casebooks (Van Gerven 1998; Van Gerven, Lever and Larouche 2000, Beale 2002; Beatson and Schrage 2003), and the 'Trento' Group is slowly unearthing the Common Core of European Private Law (Bussani and Mattei 2003; Zimmermann and Whittaker 2000; Gordley 2001; Bussani and Valentine Palmer 2003; Kieniger 2004; Sefton-Green 2005). vii The 'Lando Commission' has produced its 'Principles of European Contract Law' (Lando and 
Beale 2000; Lando 2003), the 'Tilburg Group' has produced similar principles of European Tort Law (European Group on Tort Law 2005; Wagner 2005), the Academy of European Private Lawyers in Pavia has come out with a draft European Code of Contracts (Gandolfi 2001), and the Study Group on a European Civil Code is working away on its draft articles and comparative studies (Von Bar and Drobnig 2004). ${ }^{\text {viii }}$ The project of European private law has re-energized comparative law as an academic discipline (Berger 2001; Reimann 2002), ${ }^{\mathrm{ix}}$ and has given research funding, international recognition and renewed prestige to private lawyers; the subject has also prompted calls for a 'new legal science' breaking down the barriers between any combination of private law doctrine, comparative law, Community law, legal history, and international private law (Zimmermann 1995; Joerges 2004).

Some of this work is surely driven by intellectual curiosity and a thirst for knowledge. But a large part of the success of the discipline is undeniably rooted in the political and financial support for the idea of harmonizing private law given by the European institutions from the very early days (Hallstein 1964; Witz 2003). ${ }^{x}$ The idea for the Commission on European Contract Law came from a conversation over dinner in Tivoli Gardens after a conference in Copenhagen between Professor Ole Lande and Winfried Hauschild of the European Commission where the latter informed the former that that 'we' needed a European Code. Lande then went on the search for 'qualified people,' meetings were held in Brussels, the Commission provided some funding, and in 1982 the 'Lando Commission,' a group of highly regarded professors of private law from all EC Member States, started the task of working out Principles of European Contract Law (Lando 1983, 1997, 
2001). ${ }^{x i}$ In 1989, the European Parliament passed a Resolution requesting that a start be made on drawing up a "common European Code of Private Law" and calling for "moral and material encouragement to studies of comparative law carried out within the Community and to codifying endeavours in general." ${ }^{\text {.xii }}$ In 1994, the Parliament repeated its call for a Code to be drawn up and urged support to the Lando Commission. ${ }^{\text {xii }}$ In 1998, Professor Christian von Bar established the Study Group on a European Civil Code. Whether this was the original intention or not, the Study Group has become the successor of, rather than a rival to, the Lando Commission, absorbing into its ranks a good many members of the latter group. In 2001, the Commission resurfaced in the story with the publication of its Communication on European Contract Law, launching a round of consultations on two serious options: one to promote the development of common contract law principles leading to more convergence of national laws, the other to adopt comprehensive legislation at the EC level. ${ }^{\text {iv }}$ The European Parliament wasted little time to make clear that these options should be seen sequentially rather than as alternatives. It even laid out a timetable: the comparative research on common principles and terminology should be finished by 2005; from that year, the newly found treasures are to be disseminated in academic training and the legal profession, so that by 2010 a body of rules on contract law can be adopted in the European Union. ${ }^{\mathrm{xv}}$ The Commission came out in 2003 with an Action Plan, where it was careful to deny plans for a full-blown top-down civil code. Instead, it announced its intention to concentrate efforts on developing what is now called a "Common Frame of Reference," a model code of contract law. (Kenny 2003) There, it stated: 
"[l]t should be emphasized that it is not the Commission's intention to 're-invent the wheel' in terms of research activities. On the contrary, it is remarkable that never before in the area of European contract law has there been such a concentration of ongoing research activities. It is essential that these research activities are continued and exploited to the full. Therefore, the main goal is to combine and co-ordinate the ongoing research in order to place it within a common framework following several broad approaches."xvi

In an extraordinary use of the Union's research and development budget, this has now been achieved by gathering and co-opting many of the players in the burgeoning field in the 'Joint Network on European Private Law', a Network of Excellence funded to the tune of five million Euros by the Commission under the Sixth Framework Programme for research from May 2005 onwards. The research project is explicitly geared towards delivering a proposal for a Common Frame of Reference (CFR) as requested by the Commission in the form of Common Principles of European Contract Law. To supplement academic excellence, the Commission has also established a "network of stakeholders" dubbed CFR-net. The network is meant to represent a "variety of legal traditions" and a "balance of economic interests," objectives it falls far short of. (Hesselink 2005)

The CFR is to provide a common vocabulary and assist arbitrators, courts, national legislators, and the Community legislator in their work (Staudenmayer 2002, 2005). Its eventual legal status is said to be open for discussion, and will depend in large 
part on the degree of voluntary use and indirect influence it will exert. The Commission's ambiguity on the idea of full harmonization, however, is palpable, and leads in turn to further divergences among the European institutions. In November 2005, the Competitiveness Council explicitly welcomed the Commission's "repeated reassurance" that it does not intend to propose a European civil code. ${ }^{\text {xviii }}$ The European Parliament, on the other hand, is more prone to conspiracy theories. In its March 2006 Resolution on the matter, it states that, "even though the Commission denies that this is the objective, it is clear that many of the researchers and stakeholders working on the project believe that the ultimate long-term outcome will be a European code of obligations or even a fullblown European civil code. ${ }^{\text {"xix }}$ The Parliament then goes on to assert the primacy of the body politic over academic stealth:

"Whereas the decision to work towards and on such a code must be taken by the political authorities, since the very decision to opt for a Code is political and its content, albeit legal, is predicated on social and political objectives; whereas, given that in the future the political will may well exist to adopt such a Code, it is essential that the present work be done well and with the appropriate political input;

Whereas the final product of the initiative should be open to amendment by the EC legislature and should be formally adopted by it." ${ }^{\prime x}$

\section{The Case for European Private Law}


The rationales offered for harmonizing private law are tied up in different ways with the logic of market integration. The blunt variety is ruthlessly economic and posits the project as a market opening measure. As Lando makes the case in a simple syllogism:

\begin{abstract}
"The foreign laws are often difficult for the businessman and his local lawyer to understand. They make him feel insecure, and may keep him away from foreign markets in Europe. Thus, the existing variety of contract laws in Europe may be regarded as a non-tariff barrier to trade. It is the aim of the Union to do away with restrictions of trade within the Communities, and therefore the differences of law which restrict this trade should be abolished." (Lando 1998; Basedow 1996b; Racine 2003)
\end{abstract}

In days of old, such reasoning might have been enough to establish Community competence. With modern constitutional sensitivities in the Union, however, it falls far short, especially in the absence of overwhelming empirical evidence. ${ }^{x x i}$ The more sophisticated argument is defensive, and sees to the various ways that European Community law is creating fragmentation within national private law systems (Schmid 2002; Steindorff 1996; Schepel 2004). As correcting measures to the deregulatory pressures exercised by the regime on the free movement of goods, persons and services, the Community has been passing a series of consumer protection Directives on, for example, unfair contract terms, product liability, time sharing, and electronic commerce that Member States need to implement, sometimes by amending their civil codes or just by passing piecemeal 
legislation with all sorts of implications for the coherence of national legal systems. (Teubner 1998; Roth 2002). As Von Bar expresses his impatience:

"European jurists sense that matters cannot stay the way they are with the present approach to lawmaking in the institutions of the European Union. Many directives are only a harmonization success story from the perspective of Brussels: from the perspective of national legal systems, they lead to new fault lines. The further Brussels intrudes into the private law of the Member States, the more one is directed to a common terminology. The current sectoral and 'piecemeal' approach of Directives, exclusively conceived from the perspective of consumer protection law, is already placing the quality and systematic coherence of our national systems of private law in permanent danger." (Von Bar 2002, 385)

The European Council has very recently admitted the sorry state of this legislation, calling for its quality and coherence to be improved by "measures of consolidation, codification and rationalization." "xxii For European private lawyers, however, this way of tinkering with EC legislation largely misses the point. To merely concentrate on the ignorance of 'Brussels' in matters of private law is, in this view, to overlook the systemic problems posed by European law. The quality and coherence of national systems of private law is not something that 'better' piecemeal legislation can ultimately maintain: it is something that only a truly European science of private law can guarantee. 


\section{The Role of Legal Science in European Private Law Discourse}

The CFR would seem to have settled, for the time being at least, the "Thibaut $v$. Savigny" debate in European private law (Lando 1992, 1997, 2000; Kötz 2002; Basedow 2004). The role of Savigny, with particular fondness for Roman law and all, has been taken on with pride and zeal by Reinhard Zimmermann. The great codifications of the nineteenth century, so he claims, are but "a transitional stage within an ongoing tradition" of European private law (Zimmermann 1995, 105). In spite of the nationalization of law and legal science, it is still possible to find "common systematic, conceptual, institutional and ideological foundations" beneath the "bewildering diversity and specificity of our modern legal rules." (Zimmermann 1996, 600) But to uncover these we need a new historical legal science, and certainly not offerings from Brussels or Luxembourg: "Like Savigny, we should put our faith in an organically progressive science rather than the legislature." (Zimmermann 1995, 105).

Zimmermann's ideas have attracted criticism from various sources, most notably and viciously perhaps from Ugo Mattei who accuses him of having the same "ethno-centric, conservative, class-privileged, self-serving attitude" as Savigny himself (Mattei 1998, 884) and of fighting a battle to avoid losing his status in the sociological shake-up of the European academic nomenklatura that would inevitably be the result of the creation of the Code:

"All of this can be avoided if the issue of codification is constructed as academic and if it is maintained within a highly homogeneous European legal academic elite (a sort of old boys club) who, rather appealingly, argue to close the gates and defeat the Brussels 
Eurocrats. However, the real agenda is different. In avoiding the political process, which is less homogeneous and less pluralistic than legal academia, some legal scholars are more likely to keep their role of hidden lawgivers." (Mattei 1998, 886)

What the Common Frame of Reference provides is a way to alter the terms of engagement in the debate from 'politics versus academia' to 'top down versus bottom up.' However pluralistic and non-elitist the Community legislator may be, very few people in Europe today would entrust it with a "forward-looking exercise in social engineering like the building of a common law of Europe." (Mattei 1998, 890) The role of legal science, then, is not as a handmaiden to the powers that be, nor as an autonomous source of law, but as a transmission belt between the social and political spheres in an organic process. As Gerhard Wagner writes, "the avalanche of emotions, thoughts and arguments triggered by the suggestion of full harmonization must not bury the beautiful flower of soft harmonization, i.e. the approximation of European legal systems through a creeping process of academic teachings and writings, inspired, focused and reinforced by restatements of the common law of Europe." (Wagner 2005, 1270) The growing acceptance by legal professionals and economic operators, then, of a body of rules "gradually maturing from within the field of European expertise in private law' will lead to a gradual increase in legally binding force." (Von Bar 2002, 385) On this organic theory, Von Bar and others can justify their charismatic leadership and control over their "fiefdoms" in the name of academic excellence unpolluted by political convenience. (Markesinis 2004, 574) 
It is, of course, the eventual success of Thibaut and others in the nineteenth century that creates the main obstacle to the Europeanization of contemporary private law: Member States are all endowed with national systems of private law that have created "similar customs and habits," that have been credited with nation-building and the forging of national identity and have been taken to reflect and express deep cultural values (Collins 1995; Lequette 2002, 2003). Its detractors, then, claim that harmonization of private law will produce "a new separation between the legal-political function and social life." (Legrand 1997, 53, 1996). European private lawyers sometimes react with irritation to these objections. Basedow speaks of "the strange ideology shared by so many lawyers all over the world that law is deeply rooted in the culture of each nation and as such unfit for international uniformity." (Basedow 1998, 127) Lando objects that "contract law is not folklore; it is a question of ethics, economics and technique." (Lando 2000, 826) But generally the new field of European private law is even more drenched in the symbolism and associations with state-building of private law codification than are the provincial guardians of legal nationalism in contrast with which it has built its identity. That private law is a part of a people's history, culture, and identity is not something that European private lawyers will argue over. Indeed, Von Bar is dismayed that the Commission does not even consider the "symbolic force" of a uniform European private law worthy of a mention. But, "it is collective responsibility for private law that is at stake, not modes of expressing national sovereignty; it is culture that is at issue, to be sure, but it is the culture of a truly European private law." (Von Bar 2002, 385) This is Ole Lando's upbeat appraisal of the sociological preconditions for the unification of European private law: 
"[M]ost of the guardians and preachers of our law and justice grew up in well to do bourgeois homes with moral traditions. In Europe the middle class has in fact been the guardian of ethics and so have, in general, the parents of the judges and professors. Their fathers were there, and behaved themselves. In school and at the universities the lawyers in spe were good, relatively virtuous students with strong ties to their homes. Many of them were rightwingers. Their professional life has maintained their bourgeois attitudes, and has confirmed their conservative response to life.... Thus, the legal values of the European brotherhood of lawyers are very similar. And so are, it is submitted, the legal values of the European peoples who live in societies of a similar economic and political structure and share the same ethics. This should enable us to make a European Code of Obligations." (Lando 1998, 825)

The role of learned jurists in European private law's conception of a common legal culture is either crudely elitist or fully tautological or both. But the shared ideas about the power of shared ideas are tenacious. As it turns out, law-as-science is European legal culture. In Basedow's thinking, a feeling of "togetherness" of European lawyers by itself will generate a true European legal culture and a common European legal consciousness. The building stones on which to construct this feat are the "rule of law" expressed by the authority of general abstract legal rules, the systematization of law by legal science, and the technicality of law as the domain of legal scientists under exclusion of laypeople. (Basedow 1996a, 379) 
European legal culture hence exists of learned jurists coming together to celebrate their common detachment.

With Von Bar and Lando, the Europeanization of private law "can only be achieved by an impartial formulation of principles in the light of detailed comparative law research, transcending legal diversity by a dispassionate development of the most appropriate rules for a Community wide private law. Any other method would be entirely inappropriate." (Von Bar, Lando and Swann 2004, 239) This "scholarly activism" has long been tolerated here, encouraged there, and ignored almost everywhere outside of a little circle of learned circles. The political debate over the distributive effects of a common contract law has only just begun (Kennedy 2002; Hesselink 2004), but has been given enormous impetus by the publication of the manifesto of the Study Group on Social Justice in European Private Law (Study Group 2004). That debate, this time around, is not being fought between those learned jurists in representation of the dispossessed and those representing their own bourgeois values: the battle is fought between learned jurists looking to maintain private law a matter for themselves and those who seek an open, accountable, and representative process to discuss the political import of a Code. Substance and procedure, however, are inexorably linked in European private law science.

\section{Conclusion}

The project of a European civil code is legitimized on the one hand by its scientific sophistication - and isolation from 'political' pressure - and on the other hand by 
grand historic theorizing about the common legal heritage of Europe and sociological claims about the cultural, social and political functions of private law science in society. Indeed, the fundamental move behind the enterprise is the collapse of these two strands of legitimization discourse. Intellectually, these ideas may or may not be taken seriously. Sociologically, they need to be understood as important means to maintain the unity, autonomy and hence the authority of the legal field. And that, in turn, should enable us better to grasp the extent to which European integration is a legal process. 


\section{References}

Note: All primary sources of German nineteenth century private law cited with their original dates of publication are available in full in the digital library of the MaxPlanck-Institute for European Legal History in Frankfurt am Main: http://dlibpr.mpier.mpg.de/index.htm.

Alter, Karen. 2001. Establishing the Supremacy of European Law: The Making of an International Rule of Law in Europe. Oxford: Oxford University Press.

Bach, Maurizio. 1999. Die Bürokratisierung Europas. Frankfurt: Campus.

Von Bar, Christian, 1998. The Common European Law of Torts. Vol. 1, Oxford: Oxford University Press.

Von Bar, Christian, 2000. The Common European Law of Torts. Vol. 2, Oxford: Oxford University Press.

Von Bar, Christian. 2002. From Principles to Codification: Prospects for European Private Law. Columbia Journal of European Law 8: 379-388.

Von Bar, Christian, Ole Lando and Stephen Swann. 2002. Communication on European Contract Law: Joint Response of the Commission on European Contract Law and the Study Group on a European Civil Code. European Review of Private Law 10: 183. 
Von Bar, Christian, and Ulrich Drobnig. 2004. The Interaction of Contract Law and Tort and Property Law in Europe. Berlin: Sellier.

Basedow, Jürgen. 1996a. Rechtskultur- zwischen nationalem Mythos und europäischem Ideal. Zeitschrift für Europäisches Privatrecht 3: 379.

Basedow, Jürgen. 1996b. A Common Contract Law for the Common Market. Common Market Law Review 33: 1169-1195.

Basedow, Jürgen. 1998. The Renascence of Uniform Law: European Contract Law and Its Components. Legal Studies 18: 121-145.

Basedow, Jürgen. 2004. Ein optionales Europäisches Vertragsgesetz- opt-in, optout, wozu überhaupt? Zeitschrift für Europäisches Privatrecht 12: 1-4.

Beale, Hugh et al., eds. 2002. Contract Law. Oxford: Hart Publishing.

Beatson, Jack, and Eltjo Schrage. 2003. Unjustified Enrichment. Oxford: Hart Publishing.

Berger, Klaus Peter. 2001. Harmonisation of European Contract Law - The Influence of Comparative Law. International and Comparative Law Quarterly 50: 877. 
Beseler, Georg. 1843. Volksrecht und Juristenrecht. Leipzig.

Bourdieu, Pierre. 1987. The Force of Law: Toward a Sociology of the Juridical Field. Hastings Law Journal 38: 814-853.

Bussani, Mauro, and Ugo Mattei. 2003. The Common Core of European Private Law. Deventer: Kluwer.

Bussani, Mauro, and Vernon Valentine Palmer, eds. 2003. Pure Economic Loss in Europe. Cambridge: Cambridge University Press.

Cohen, Felix S. 1935. Transcendental Nonsense and the Functional Approach. Columbia Law Review 809-849.

Collins, Hugh. 1995. European Private Law and the Cultural Identity of States. European Review of Private Law 3: 353-365.

European Group on Tort Law. Principles of European Tort Law. 2005. Wien: Springer.

Frankenberg, Günter. 2006. How to Do Projects with Comparative Law - Notes of an Expedition to the Common Core. Global Jurist Advances 6 (2). www.bepress.com/gj/advances/vol6/iss2/art1. 
Gale, Susan Gaylord. 1982. A Very German Legal Science: Savigny and the Historical School. Stanford Journal of International Law 18: 123-146.

Gandolfi, Giuseppe, ed. 2001. Code européen des contrats. Vol. 1: Avant-project. Milan: Giuffrè.

Van Gerven, Walter. 1998. Tort Law- Scope of Protection. Oxford: Hart Publishing.

Van Gerven, Walter. 2002. Codifying European Private Law? Yes, if...! European Law Review 156-176.

Van Gerven, Walter. 2004. Harmonization of Private Law: Do We Need It? Common Market Law Review 41: 505-532.

Van Gerven, Walter, Jeremy Lever, and Pierre Larouche. 2000. Tort Law. Oxford: Hart Publishing.

Von Gierke, Otto. 1889. Der Entwurf eines bürgerlichen Gesetzbuchs und das deutsche Recht. Leipzig.

Gordley, James, ed. 2001. The Enforceability of Promises in European Contract Law. Cambridge: Cambridge University Press.

Graziadei, Michele, Ugo Mattei and Lionel Smith, eds. 2005. Commercial Trusts in European Private Law. Cambridge: Cambridge University Press. 
Grundmann, Stefan, and Jules Stuyck, eds. 2002. An Academic Green Paper on European Contract Law. Deventer: Kluwer.

Guterman, Simeon L. 1966. Law and History in the Making of European Unity. New York Law Forum 12: 430-457.

Häberle, Peter. 1994. Europäische Rechtskultur. Baden-Baden: Nomos.

Haferkamp, Hans-Peter. 2004. Georg Friedrich Puchta und die 'Begriffsjurisprudenz.' Frankfurt a.M.: Klostermann.

Hallstein, Walter. 1964. Angleichung des Privat- und Prozessrechts in der Europäischen Wirtschaftsgemeinschaft. Rabels Zeitschrift 28: 211.

Hartkamp, Arthur, et al., eds. 1994. Towards a European Civil Code. Deventer: Kluwer.

Hesselink, Martijn W. 2002. The New European Private Law. Deventer: Kluwer.

Hesselink, Martijn W. 2004. The Politics of a European Civil Code. European Law Journal 10: 675-697.

Hesselink, Martijn W. 2005. Editorial. Who has a stake in European contract law? European Review of Contract Law 1: 295-296. 
Van Hoecke, Mark, and François Ost, eds. 2000. The Harmonisation of European Private Law. Oxford: Hart Publishing.

Joerges, Christian. 2004. The Challenges of Europeanization in the Realm of Private Law: A Plea for a New Legal Discipline. Duke Journal of Comparative and International Law 14: 149-196.

John, Michael F. 1985. The Politics of Legal Unity in Germany, 1870-1896. The Historical Journal 28: 341-355.

John, Michael F. 1989. Politics and the Law in Late Nineteenth-Century Germany: The Origin of the Civil Code. Oxford: Clarendon Press.

Kennedy, Duncan. 2002. The Politics of "Merely Technical" Issues of Contract Law. European Review of Private Law 10: 7-28.

Kenny, Mel. 2003. The 2003 Action Plan on European Contract Law: Is the Commission Running Wild? European Law Review 28: 538-550.

Kieninger, Eva-Maria, ed. 2004. Security Rights in Moveable Property in European Private Law. Cambridge: Cambridge University Press.

Von Kirchmann, Julius Hermann. 2000 (1848). Die Wertlosigkeit der Jurisprudenz als Wissenschaft. Heidelberg: Manutius. 
Kötz, Hein. 1998. European Contract Law. Translated by Tony Weir. Oxford: Clarendon.

Kötz, Hein. 2002. Savigny v Thibaut und das gemeineuropäische Zivilrecht. Zeitschrift für Europäisches Privatrecht 10: 431-435.

Lando, Ole. 1983. European Contract Law. American Journal of Comparative Law 31: 653-659.

Lando, Ole. 1992. Principles of European Contract Law: An Alternative to or a Precursor of European Legislation? American Journal of Comparative Law 40: 573-585.

Lando, Ole. 1997. Why Codify the European Law of Contract? European Review of Private Law 5: 525-536.

Lando, Ole. 1998. Guest Editorial: European Contract Law After the Year 2000. Common Market Law Review 35: 821-831.

Lando, Ole. 2000. Optional or Mandatory Europeanisation of Contract Law. European Review of Private Law 4: 59-69.

Lando, Ole. 2001. Comparative Law and Lawmaking. Tulane Law Review 75: 1015-1032. 
Lando, Ole, and Hugh Beale, eds. 2000. Principles of European Contract LawParts I and II. The Hague: Kluwer.

Lando, Ole, et al., eds. 2003. Principles of European Contract Law-Part III. The Hague: Kluwer.

Legrand, Pierre. 1996. European Legal Systems Are Not Converging. International and Comparative Law Quarterly 45: 53-81.

Legrand, Pierre. 1997. Against a European Civil Code. Modern Law Review, 60: 44-63.

Lequette, Yves. 2002. Quelques remarques à propos du projet de code civil européen de M. von Bar. Recueil Dalloz 2202-2214.

Lequette, Yves. 2003. Vers un code civil européen. Pouvoirs, (107): 97.

López-Rodríguez, Ana M. 2004. Towards a European Civil Code Without a Common European Legal Culture? The Link Between Law, Language and Culture. Brooklyn Journal of International Law 29: 1195-1220.

Madsen, Mikael Rask, and Yves Dezalay. 2002. The Power of the Legal Field:

Pierre Bourdieu and the Law. In An Introduction to Law and Social Theory, eds. Reza Banakar and Max Travers. Oxford: Hart Publishing, 189-204. 
Markesinis, Basil. 2004. Two Hundred Years of a Famous Code: What Should We Be Celebrating? Texas International Law Journal 39: 561-579.

Mattei, Ugo. 1998. The Issue of European Civil Codification and Legal Scholarship: Biases, Strategies and Developments. Hastings International and Comparative Law Review 21: 883-902.

Mattei, Ugo. 2003. The European Codification Process: Cut and Paste. Deventer: Kluwer.

Menger, Anton. 1890. Das Bürgerliche Recht und die besitzlosen Volksklassen. Tübingen.

Muir-Warr, Horatia. 2004. Experiences From Europe: Legal Diversity and the Internal Market. Texas International Law Journal 39: 429-459.

Müller-Graff, Peter-Christian, ed. 1999. Geimeinsames Privatrecht in der Europäischen Gemeinschaft. $2^{\text {nd }}$ ed. Baden-Baden: Nomos.

Niglia, Leone. 2002. The Transformation of Contract in Europe. Deventer: Kluwer.

Puchta, Georg Friedrich. 1854. Vorlesungen über das heutige römische Recht. $4^{\text {th }}$ ed., 2 vols. Leipzig. 
Racine, Jean-Baptiste. 2003. Pourquoi unifier le droit des contrats en Europe?

Plaidoyer en faveur de l'unification. Revue du Droit de l'Union européenne. (2): 369-407.

Reimann, Mathias. 1990. Nineteenth Century German Legal Science. Boston College Law Review 31: 837-897.

Reimann, Mathias. 1991. Roman Law as a Political Agenda. Michigan Law Review 89: 1679-1693.

Reimann, Mathias. 2002. The Progress and Failure of Comparative Law in the Second Half of the Twentieth Century. American Journal of Comparative Law 50: 671.

Roth, Wulf-Henning. 2002. Transposing "Pointillist" EC Guidelines into Systematic National Codes- Problems and Consequences. European Review of Private Law 6: 761-776.

Von Savigny, Friedrich Carl. 1814. Vom Beruf unserer Zeit für Gesetzgebung und Rechtswissenschaft Berlin.

Von Savigny, Friedrich Carl. 1840. System des heutigen römischen Rechts. Vol. 1. Berlin. 
Schepel, Harm. 2004a. Law, Lawyers and Legal Integration. EUSA Review 17(4):

1 (http://www.eustudies.org/Fall2004ReviewForu.pdf)

Schepel, Harm. 2004b. The Enforcement of EC Law in Contractual Relations:

Case Studies in How Not to 'Constitutionalise' Private Law. European Review of Private Law 12: 661-675.

Schepel, Harm, and Rein Wesseling. 1997. The Legal Community: Judges, Lawyers, Officials and Clerks in the Writing of Europe. European Law Journal, 2: 165.

Schmid, Christoph U. 1999. The Emergence of a Transnational Legal Science in European Private Law. Oxford Journal of Legal Studies 19: 673-689.

Schmid, Christoph U. 2002. Pattern of Legislative and Adjudicative Integration of Private Law. Columbia Journal of European Law 8: 415-486.

Sefton-Green, Ruth, ed. 2005. Fraud, Mistake and Duties to Inform in European Contract Law. Cambridge: Cambridge University Press.

Staudenmayer, Dirk. 2002. The Commission Communication on European Contract Law and the Future Prospects. International and Comparative Law Quarterly 51: 673-688. 
Staudenmayer, Dirk. 2005. The Way Forward in European Contract Law. European Review of Private Law 13: 95-104.

Stein, Peter. Roman Law in European History. 1999 (1996). Cambridge: Cambridge University Press.

Steindorff, Ernst. 1996. EG-Vertrag und Privatrecht. Baden-Baden: Nomos.

Stone Sweet, Alec. 2004. The Judicial Construction of Europe. Oxford: Oxford University Press.

Stone Sweet, Alec, and Neil Fligstein. 2002. Constructing Polities and Markets: An Institutionalist Account of European Integration. American Journal of Sociology 107: 1206.

Study Group on Social Justice in European Private Law. 2004. Social Justice in European Contract Law: A Manifesto. European Law Journal 10: 653-674.

Teubner, Gunther. 1998. Good Faith in British Law, or How Unifying Law Ends Up in New Divergences. Modern Law Review 61: 11.

Thibaut, Anton Friedrich Justus. 1814. Über die Notwendigkeit eines allgemeinen bürgerlichen Rechts in Deutschland. 
Vogenauer, Stefan. 2005. An Empire of Light? Learning and Lawmaking in the History of German Law. Cambridge Law Journal, 64: 481-500.

Vogenauer, Stefan, and Stephen Weatherill. 2005. The European Community's Competence for a Comprehensive Harmonisation of Contract Law - An Empirical Analysis. European Law Review, 30: 821-837.

Vogenauer, Stefan, and Stephen Weatherill, eds. 2006. The Harmonisation of European Contract Law. Implications for European Private Laws, Business, and Legal Practice. Oxford: Hart Publishing.

Wagner, Gerhard. 2005. The Project of Harmonizing European Tort Law. Common Market Law Review, 42: 1269-1312.

Weatherill, Stephen. 2002. The Commission's Options for Developing EC Consumer Protection and Contract Law: Assessing the Constitutional Basis. European Business Law Review 497-515.

Weber, Max. 1978. Economy and Society. Guenther Roth and Claus Wittich, eds. Berkeley: University of California Press.

Whitman, James Q. 1990. The Legacy of Roman Law in the German Romantic Era. Historical Vision and Legal Change. Princeton: Princeton University Press. 
Wieacker, Franz. 1990. Foundations of European Legal Culture. American Journal of Comparative Law 38: 1.

Wieacker, Franz. 1996 (1952). A History of Private Law in Europe, with particular reference to Germany. Translated by Tony Weir. Oxford: Clarendon Review 541-555.

Windscheid, Bernhard. 1870. Lehrbuch des Pandektenrechts $3^{\text {rd }}$ ed. 2 vols. Düsseldorf.

Witz, Claude. 2003. La longue gestation d'un code européen des contrats. Rappel de quelques initiatives oubliées. Revue Trimestrielle de Droit Civil 447-454.

Wurmnest, Wolfgang. 2003. Common Core, Grundregeln, Kodifikationsentwürfe, Acquis-Grundsätze- Ansätze internationaler Wissenschaftlergruppen zur Privatrechtsvereinheitlichung in Europa. Zeitschrift für Europäisches Privatrecht 11: 714-744.

Zimmermann, Reinhard. 1995. The "Europeanization" of Private Law within The European Community and the Re-emergence of a European Legal Science. Columbia Journal of European Law 1: 63-105.

Zimmermann, Reinhard. 1996. Savigny’s Legacy: Legal History, Comparative Law and the Emergence of a European Legal Science. Law Quarterly Review 112: 576. 
Zimmermann, Reinhard, and Simon Whittaker, eds. 2000. Good Faith in European Contract Law. Cambridge: Cambridge University Press.

\footnotetext{
${ }^{\mathrm{i}}$ Thibaut reserved the later qualification for the French code civil of 1804.

ii Law is produced "durch innere, stillwirkende Kräfte, nicht durch die Willkühr eines Gesetzgebers" (Savigny 1814, 14).

iii But only just. The "new organic life" of the law in the consciousness of learned jurists is such that legal science can become "eine neue Art der Rechtserzeugung" (Savigny 1814, 46). Savigny was characteristically unconcerned about charges of illegitimate power for this class of jurists. After all, "anyone who applies himself can become a lawyer." (Savigny
} $1840,45)$

${ }^{\text {iv }}$ Anton Menger felt it his duty to write his socialist critique of the draft code since he was one of the few learned jurists able and willing to represent the dispossessed (Menger 1890, 2).

${ }^{\vee}$ See, for example, the Zeitschrift für Europäisches Privatrecht, first published in 1992, the European Review for Private Law, 1993; the Zeitschrift für Gemeinschaftsprivatrecht, 2003; and the European Review of Contract Law, 2005.

${ }^{\mathrm{vi}}$ See, for example, Duncker and Humblot's series Untersuchungen zum Europäischen Privatrecht; Kluwer's Private Law in European Context series, and Sellier's Principles of European Law.

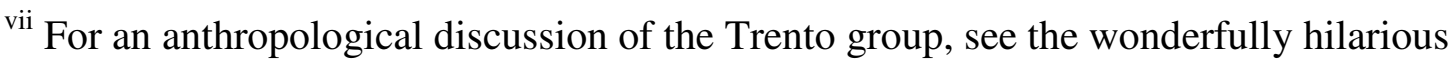
account in Frankenberg 2006.

viii The proposed Articles are published on http://www.sgecc.net. 
${ }^{\text {ix }}$ Reimann, though, is harsh on the intellectual worth of all of this, dismissing it as a "soundly positivistic, methodologically simplistic, and amazingly biased enterprise." (Reimann 2002, 693; Legrand 1996).

${ }^{\mathrm{x}}$ Walter Hallstein, a law professor before he embarked on a political career, was the first president of the European Commission (1958-1968).

${ }^{x i}$ Lando tells the story in his preface to Lando and Beale 2000.

xii European Parliament Resolution on action to bring into line the private law of the Member States, (1989) OJ C 158/400.

xiii European Parliament Resolution on the harmonization of certain sectors of the private law of the Member States, (1994) OJ C 205/518.

${ }^{\text {xiv }}$ Communication from the Commission on European contract law, COM (2001) 398.

${ }^{\mathrm{xv}}$ European Parliament Resolution on the approximation of the civil and commercial law of the Member States, (2002) OJ C 140 E/538.

${ }^{x v i}$ Commission Communication, A More Coherent European Contract Law - An Action Plan, COM (2003) 68, p. 18. See also the follow-up, Commission Communication, European Contract law and the revision of the acquis: the way forward, COM (2004) 651 final.

${ }^{x v i i}$ The stakeholder network was announced in Commission Communication, European Contract law and the revision of the acquis the way forward, COM (2004) 651 final. See further Commission report, First Annual progress Report on European Contract Law and the Acquis Review, COM (2005) 456 final.

${ }^{x v i i i}$ Paragraph 9, Council Conclusions on European Contract Law, Competitiveness Council, 28-29 November 2005

${ }^{\text {xix }}$ European Parliament, Resolution on European Contract Law and the revision of the acquis, 23 March 2006, A6-0055/2006. 
${ }^{\mathrm{xx}}$ Ibid.

xxi The need for cogent reasoning under Article 95 EC is much stronger than before after the ECJ's judgment in the 'Tobacco Advertising' case. See Case C-376/98 Germany $v$ Parliament and Council [2000] ECR I-8419. See e.g., Weatherill 2002; Van Gerven 2002, 2004. Von Bar is undaunted: "That diverse private law hampers the internal market is everyday experience, whether that admits of empirical evidence or not." (Von Bar 2002, 385) See, however, Vogenauer and Weatherill 2005.

xxii European Council, The Hague Programme: Strenghtening Freedom, Security and Justice in the European Union. (2005) OJ C 53/1, paragraph 3.4.4. 